\title{
Impact of regional climatic conditions on tree growth on mainland Greece
}

\author{
Panagiotis P. Koulelis*, Evangelia N. Daskalakou, Kostas E. Ioannidis
}

Institute of Mediterranean Forest Ecosystems, Athens, 11528, Greece

\begin{abstract}
Koulelis, P.K., Daskalakou, E.N., IoAnnidis, K.E., 2019. Impact of regional climatic conditions on tree growth on mainland Greece. Folia Oecologica, 46: 127-136.

Forest growth is commonly used to explore tree vitality and ability to resist to environmental changes or climatic fluctuations. This paper illustrates and examines how regional climatic conditions can be related to the decline of tree growth, which were found to be more distinct in Quercus frainetto Ten. (Hungarian oak) and Fagus sylvatica L. (European beech) and less pronounced in Abies borissi-regis Matt f. (Bulgarian fir) on three long-term intensive monitoring plots (ICP Forests-Level II) in Greece during the period 1996-2009. Relative basal area increment and volume increment were calculated, expressing tree growth in terms of mean relative annual periodic increment. A decline in the growth of basal area and volume was observed after hot and dry periods, where annual temperatures and precipitation were far from the mean of the analyzed period. This observation was statistically confirmed in oak and beech plots regarding summer precipitation only and are in agreement with the findings of previous studies in Europe. The representativeness of the results at a national scale needs further investigation, although our results provide a good basis for further and more intensive monitoring programs to address various forest management scenarios against the background of potential climatic changes in the Mediterranean area.
\end{abstract}

\section{Keywords}

Bulgarian fir, climate-growth relationship, European beech, Hungarian oak, ICP-Forests, Mediterranean forests

\section{Introduction}

Decreased precipitation, accompanied by high temperatures are most likely the main threats to the diversity and survival of Mediterranean forests (PEÑUELAS et al., 2017). Tree growth is a quantitative indicator of tree vitality and the ability to buffer environmental constrains (DOBBERTIN, 2005). Based on literature findings, warming-induced drought may intensify physiological stress on long-lived woody vegetation, leading to sudden tree growth reduction. Moreover, growth decline in response to severe droughts may trigger widespread mortality, which can reshape the stand structure, composition, and the mid-term stand dynamics and forest landscapes at regional scales
(Galiano et al., 2010). During the last decades, severe drought events, characterized by high temperatures and low precipitation, caused intense forest-dieback episodes across Europe (PeÑUElas et al., 2001; DoBBERTIN, 2005). Moreover, many recent examples of drought and heat-related tree mortality from around the world suggest that no forest type or climate zone is invulnerable to anthropogenic climate change, even in environments not normally considered water-limited (ALLEN et al., 2010). As expected, there seems to be a connection between regional climate conditions and forest growth decline in the Mediterranean forests. In addition, growth decrease was significantly less severe in sites with high moisture levels (LiNAREs et al. 2009; 2011). Mediterranean regions might

\footnotetext{
*Corresponding author: e-mail: pkoulelis@fria.gr 
become most vulnerable to tree species loss, mainly due to increased frequency and intensity of drought events (IPCC 2007; IPCC 2012). Between the periods 1997-1999 and 2000-2004, up to $50 \%$ of the examined ICP plots showed reduced growth in Italy (BERTINI et al., 2011). Similar results were observed by FABBIO et al. (2005-2006) regarding Italy. Warmer and drier climatic conditions during April were linked to enhanced defoliation in ICP-monitored forest plots in Spain (SÁNCHEZ-SALGUERo et al., 2017). Etzold et al., (2014) observed that tree growth was mostly reduced due to dry conditions during previous period. That included the hot year 2003 regarding plots in Switzerland. Ciais et al., (2005) suggested that the productivity reduction in eastern and western Europe can be explained by rainfall deficits and extreme summer heat, respectively. In general terms, the literature confirms that extreme climatic events, such as successive and intensive droughts, may cause sudden growth declines and pulses of elevated tree mortality (LINARES et al., 2009). Forest growth is among the variables measured within the intensive (Level II) forest monitoring of UN/ECE ICP-Forests (International Co-operative Programme on Assessment and Monitoring of Air Pollution Effects on Forests). One of the scopes of the Programme was to analyze the influence of stress factors on the conditions of forests in Europe (DE VRIES et al., 2003). The dynamic and periodic tree growth characteristics were systematically (almost every five years) recorded in three intensive monitoring (ICP Forests-Level II) plots in Greece, following a common European protocol. Abies borissi-regis Matt f., Fagus sylvatica $\mathrm{L}$. and Quercus frainetto Ten. are the representative and dominant species regarding the examined monitoring plots.

Bulgarian fir (Abies borissi-regis Matt f.) is an endemic tree found at the southern Balkan Peninsula, naturally distributed in Greece, Albania, Serbia, The Republic of North Macedonia, and Bulgaria (CAUdullo and TINNER, 2016). In Greece, Bulgarian fir forests extend sparsely from Northern Peloponnese up to the northern border of the country (600-2000 m), forming pure stands or stands mixed with European beech. Bulgarian fir is a slow-growing species during its early stages (AUSSENAC,
2002) and its growth is affected by late spring and summer precipitation with a variation in a south to north direction in central Greece (PAPADOPOULOS, 2016). European beech (Fagus sylvatica L.) is widely distributed in Central and Western Europe, from low elevations in the northern part of its range to higherelevations $(\geq 1,000 \mathrm{~m})$ in the south (VON WueHLISCH, 2008) and center as well. Beech forests are important ecosystems from ecological (BERGMEIER and Dimopoulos, 2001) and socio-economic points of view (Merino et al. 2007). Considering structure, they are relatively diverse, due to their past management, ranging from natural, old, and virgin forests to intensely managed stands. Their future distribution is most likely affected by the predicted climatic changes (VoN WueHLISCH, 2008); beech might be less competitive due to drought (Houston DURRANT et al., 2016), especially in its southern limits. Hungarian oak (Quercus frainetto Ten.) is an economically important tree species, native to the Balkan Peninsula, with an extended range from southeastern Europe (Italy) to Asia Minor (Turkey). Thermophilous deciduous forests with Hungarian oak, in pure or mixed stands, are widely distributed on the Greek mainland (BERGMEIER and DIMOPOULOS, 2008). In most of the times, these forests, are managed as coppice woodlands for both firewood and timber (MAURI et al., 2016), and have suffered both destructive exploitation and over-grazing.

In this context, the main scope of this paper is to examine the interaction between the relative basal area and volume increment within ICP-Forests Level II plots in Greece and regional climate fluctuations, for fir, beech and oak, during the years 1996-2009. More specifically, temperature and precipitation fluctuations are examined as significant factors that explain basal area and tree volume annual increment separately for every species and with no comparison analysis between them.

\section{Materials and methods}

The data set consisted of three ICP-Forests Level II monitoring plots. Table 1 presents the ICP-Forests Level II plot characteristics from Greece, where the growth measure-

Table 1. Plot characteristics of the three ICP-Level II representative forest ecosystems in Greece

\begin{tabular}{|c|c|c|c|c|c|}
\hline Plot & Latitude & Longitude & Aspect & Area $\left(\mathrm{m}^{2}\right)$ & Age (yr) \\
\hline \multicolumn{6}{|l|}{1 (Oak) } \\
\hline Ossa Mountain & $39^{\circ} 47^{\prime} 10^{\prime \prime}$ & $22^{\circ} 47^{\prime} 40^{\prime \prime}$ & $\mathrm{NE}$ & 2,624 & 95 \\
\hline \multicolumn{6}{|l|}{2 (Beech) } \\
\hline Ossa Mountain & $39^{\circ} 47^{\prime} 52^{\prime \prime}$ & $22^{\circ} 46^{\prime} 37^{\prime \prime}$ & $\mathrm{NE}$ & 2,733 & 130 \\
\hline \multicolumn{6}{|l|}{3 (Fir) } \\
\hline Tymfristos Mountain & $38^{\circ} 52^{\prime} 29^{\prime \prime}$ & $21^{\circ} 52^{\prime} 02^{\prime \prime}$ & $\mathrm{N}$ & 2,990 & 110 \\
\hline
\end{tabular}


ments took place. Oak and beech plots belong to habitat types with a high importance for monitoring (Dimopoulos et al., 2006). Both plots are placed on a N-NE aspect, at an elevation of 740 and $890 \mathrm{~m}$ a.s.l. for oak and beech respectively and located on Mountain Ossa, which is a mountain included in the Natura 2000 Network (GR 1420003) (Fig. 1). Finally, the mentioned forests have been characterized as aesthetic forests under the national legislation. The fir plot is located on an $\mathrm{N}$ aspect at $1.175 \mathrm{~m}$ on Mountain Timfristos. Detailed characteristics of the plots regarding vegetation status, soil conditions, etc. are reported in MICHOPOULOs et al. (2008, 2015).

The data set regarding tree growth was generated according to the guidelines of the ICP-Forests tree growth manual (Dobbertin and Neumann, 2016). This manual focused on growth assessment within Level II plots, providing a consistent methodology to collect high-quality, harmonized and comparable data at intensive monitoring plots in terms of tree and stand growth. For the assessment of the basal area and the volume of trees and stands, periodical data for diameter at breast height $(\mathrm{dbh}>5 \mathrm{~cm})$ and total height $(\mathrm{H})$ of each tree, were collected approximately every five years, considering all the marked and numbered trees per plot simultaneously with the recording of the dead and broken top trees. In particular, for dbh (tree diameter-outside bark at $1.3 \mathrm{~m}$ from ground level) measurements, a caliper or a diameter tape was used; forked trees, with the fork below $1.3 \mathrm{~m}$, were treated as two separate trees. All dendrometric measurements took place after the growth season for all species (November-December) and more specifically regarding the years 1996, 2000, 2006 and 2009. Regional meteorological data were collected from the two installed meteorological stations on the two mountains near the plots, covering the period 1996-2009. To calculate tree growth decline over short periods, we used relative growth per forest tree species and plots. In

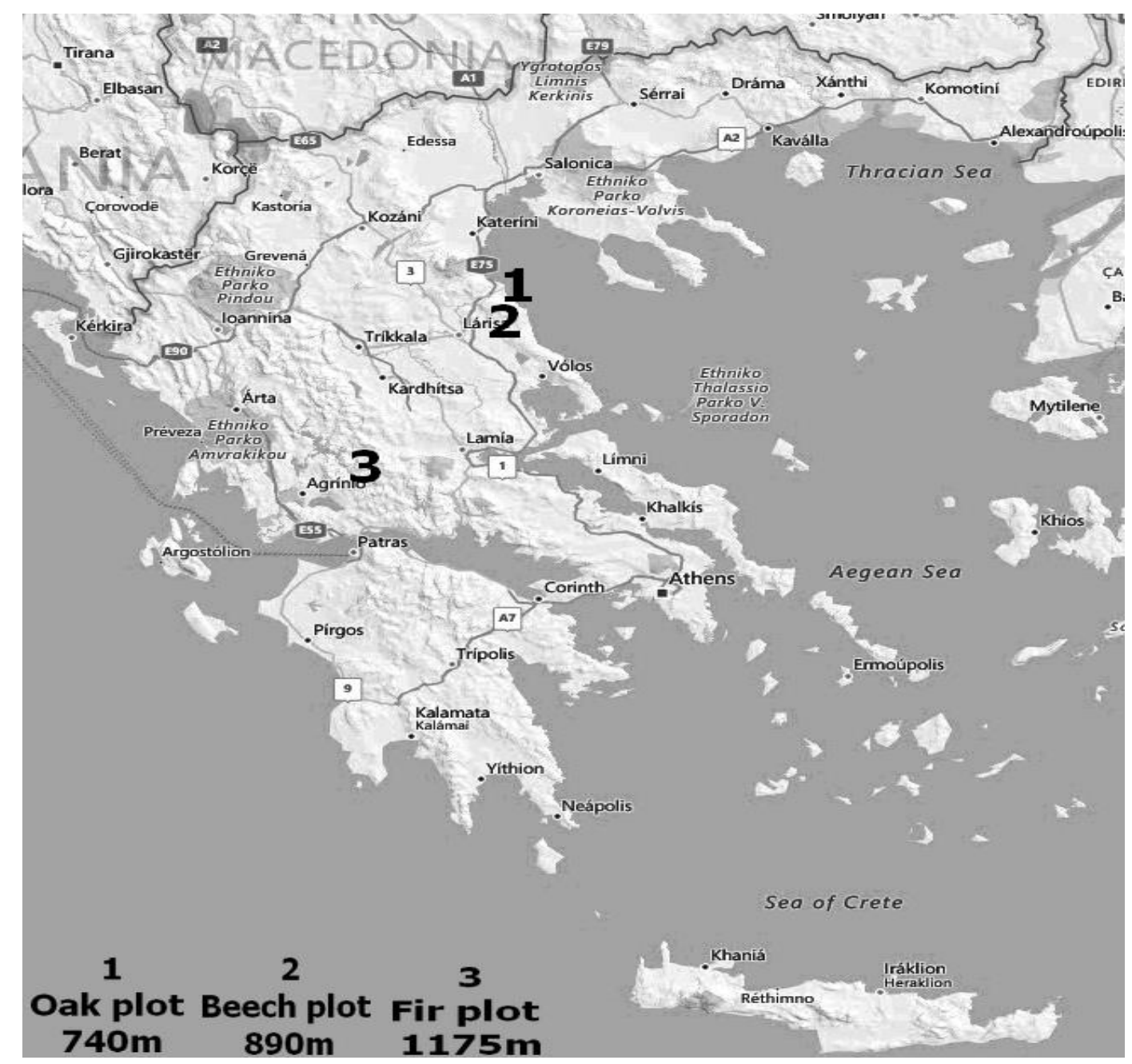

Fig. 1. ICP level II monitoring plots and the meteorological stations inside them in Greece. Source: geodata.gov.gr/maps. 
measurements, we included living marked and numbered trees in all three inventories, excluding the dead trees during the study periods. This kind of calculation expresses the volume or basal area growth in terms of mean relative annual periodic increment (MRAPI), using Pressler's formula (Pressler, 1865):

$$
\mathrm{G} \%=\frac{200}{\mathrm{n}} \frac{\mathrm{Y}_{2}-\mathrm{Y}_{1}}{\mathrm{Y}_{2}+\mathrm{Y}_{1}}
$$

where $\mathrm{G} \%$ is the relative growth, $\mathrm{n}$ are the years of the period, and Y1 and Y2, the values of basal area or bark stem volume at the beginning and the end of each period respectively. The volume calculations were made using the best fitting volume equation for national forest inventory for the specific tree species according to (APATSIDIS and SIFAKIS, 1999):

$$
\begin{aligned}
\mathrm{V}_{\text {fir }} & =\left(\frac{6.3661346}{10^{5}}\right) \times \mathrm{d}^{1.768135} \times \mathrm{h}^{1.060723} \\
\mathrm{~V}_{\text {beech }} & =\left(\frac{4.0863913}{10^{5}}\right) \times \mathrm{d}^{1.985882} \times \mathrm{h}^{0.9478463} \\
\mathrm{~V}_{\text {oak }} & =\left(\frac{2.5182532}{10^{5}}\right) \times \mathrm{d}^{1.968549} \times \mathrm{h}^{1.12419}
\end{aligned}
$$

A one way repeated measured analysis of variance (ANOVA) was conducted to evaluate if there were differ- ences in annual tree growth, i.e. basal area and volume increment, between the three study periods for each of the three species. Pearson correlation coefficient and simple regression analysis were employed in order to compare the effect of temperature and precipitation on the depended variables (annual tree growth in terms of basal area and stem volume). This particular procedure was implemented using the periodical basal area and volume values regarding the years 1996, 2000, 2006 and 2009. The constructed models were tested by their significance using $\mathrm{p}<0.05$. Considering that annual data, the missing values of the depended variables were handled with the usage of regression models statistically important $(p<0.05)$. This approach involves developing a regression equation based on the complete subject data for a given variable. Where an observation is missing, the predicted values from the regression equation are used as replacement. Afterwards, the basal area and volume increment changes per year were calculated.

\section{Results}

Temperature data (1996-2009) representing individual sites, showed a similar annual pattern with common summer peak temperatures and common low temperatures in all case studies. As expected, monthly temperatures were higher on Ossa due to its lower elevation. In terms of precipitation, similar patterns were found for all sites (Fig. 2).

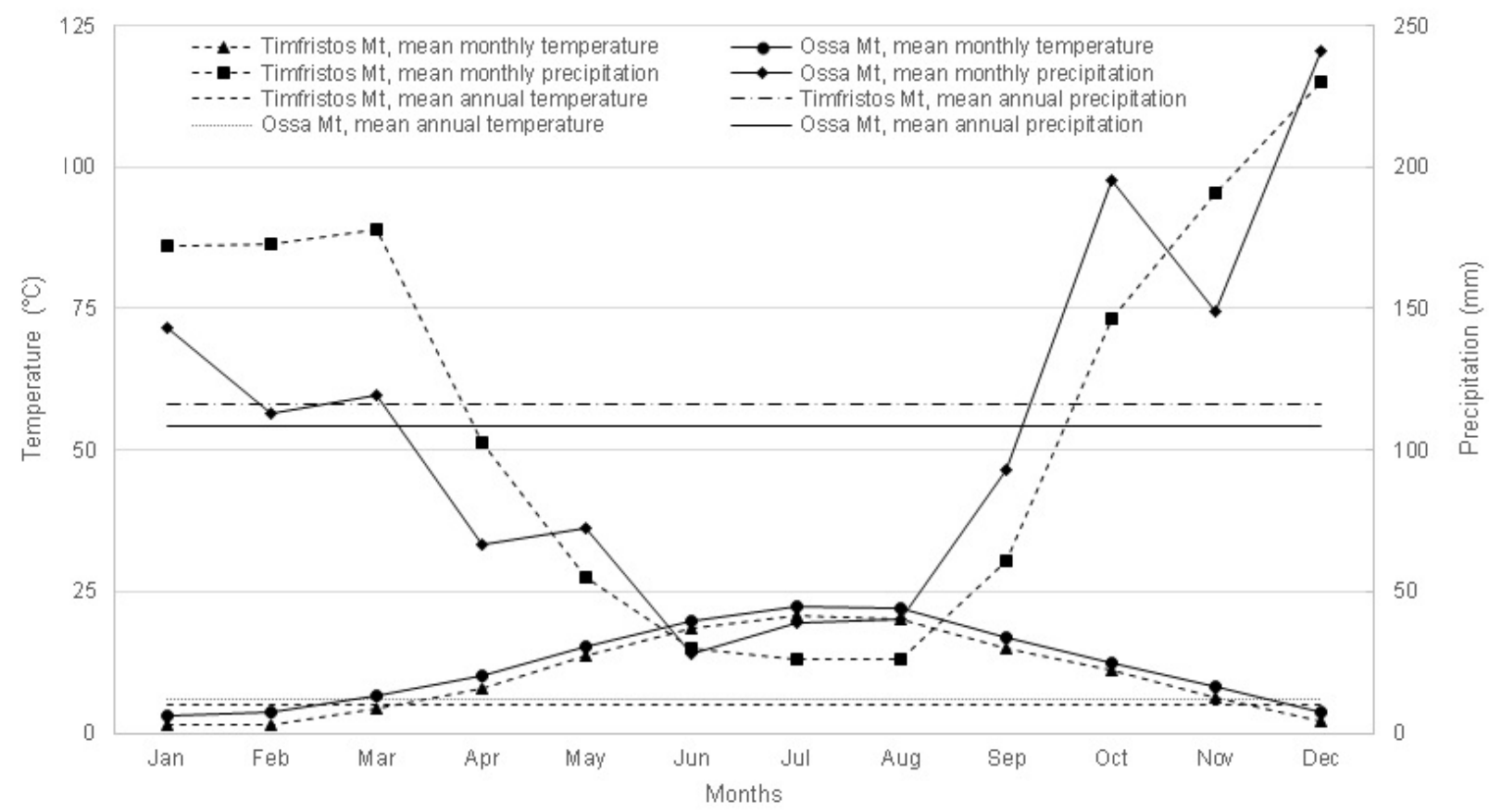

Fig. 2. Mean monthly temperature and precipitation data for meteorological stations representing each study site. The data are based on the period 1996-2009 for both stations. 
Although the monthly values varied, before May, Timfristos precipitation was higher, while from June to October, precipitation values were higher at Ossa, at least regarding the examined period.

Mean annual temperature fluctuations (Fig. 3a, c) indicated that the temperature and the corresponding growing seasons, followed similar patterns for both sites. In the case of Timfristos meteorological station, a weak increasing trend regarding temperature was observed during the entire period. In the case of Ossa meteorological station, the increasing trend was even weaker. However, we observed variations over the years. For example, the years 2000 and 2008 were the hottest on Timfristos, compared to the mean temperature, during the growing season. On the other hand, in Mt Ossa the years 2000, 2001 and 2008 were the hottest. In both cases, annual average temperatures were far from the mean of the analyzed period (i.e. $+5{ }^{\circ} \mathrm{C}$ in 2000 and $+4.5{ }^{\circ} \mathrm{C}$ in 2008 for Timfristos and almost $+4.5^{\circ} \mathrm{C}$ in 2000 and $+4.5^{\circ} \mathrm{C}$ in 2008 for Ossa) regarding the growing season values. On Timfristos, the temperature fluctuations ranged from +2.2 to $5.1{ }^{\circ} \mathrm{C}$ for growing season values and from 0.6 to $0.9{ }^{\circ} \mathrm{C}$ for mean annual values. Ossa fluctuations ranged from 2.4 to 4.8 ${ }^{\circ} \mathrm{C}$ for the growing season and from -0.1 to $1.0^{\circ} \mathrm{C}$ for the annual values. Similar patterns were recorded regarding precipitation for both sites, with variations among the years. It seems that the years 1998, 2000, 2006, 2007, and 2008 were the driest ones, according to yearly data for Timfristos (Fig. 3b). For Ossa (Fig. 3d), 2000, 2001, 2004, 2005,2007 , and 2008 were the driest years. As was expected, between the two meteorological stations, precipitation was different compared to the mean of the analyzed period 1996-2009. For instance, at the fir plot (meteorological station of Timfristos), mean annual precipitation in 2000 was almost $500 \mathrm{~mm}$ less than the average value for the entire study period $(1,431 \mathrm{~mm})$. At the beech and oak plots (meteorological station of Mt Ossa), annual precipitation for 2000 was more than $200 \mathrm{~mm}$ below the average of the entire study period $(1,302 \mathrm{~mm})$, while in 2001 , precipitation was almost $300 \mathrm{~mm}$ below the average.
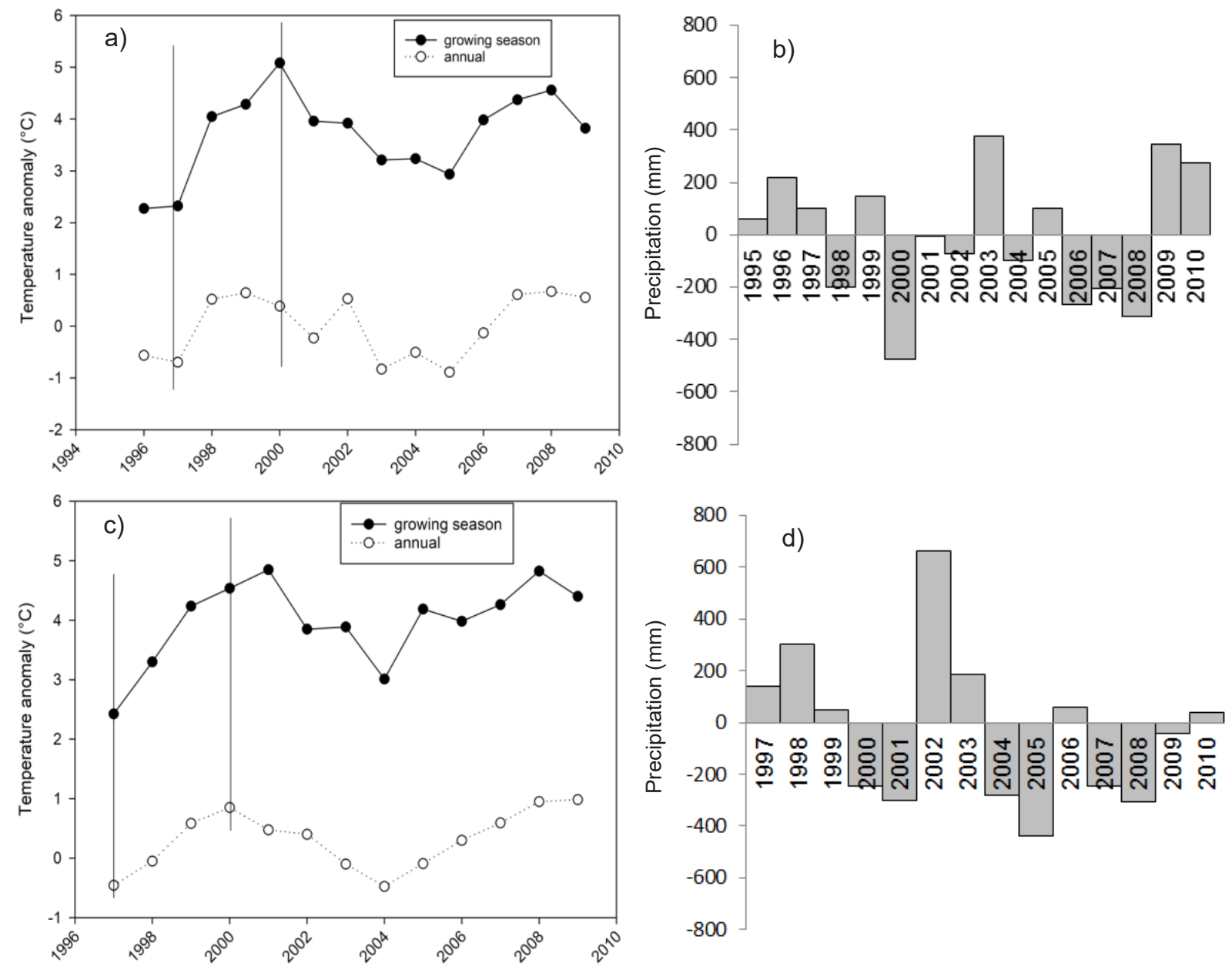

Fig. 3. Annual temperature and precipitation fluctuations compared to the corresponding mean values during the growing season (March-October) for Timfristos (a, b) and Ossa (c, d) Mountains (1996-2009). Precipitation data corresponded to each individual annual period and hot periods indicated between the vertical lines. 
At the fir plot, the period 1997-2000 was hot, with continuously increasing mean temperatures for the growing season until reached the peak in 2000 (almost $5{ }^{\circ} \mathrm{C}$ above the mean temperature of the period). In parallel, 2000 was a relatively dry year compared to the other years of the study period, with an annual precipitation decline of $45 \%$. In contrast, in central Europe, the year 2003 was characterized by an extreme drought (BERTINI et al., 2011; ETzoLD et al., 2014). The oak and beech plots were subjected to hot conditions for almost four years (1997-2000) until the peak of $2000-2001\left(\approx 4.5^{\circ} \mathrm{C}\right.$ above the mean; Fig. 3c). At the same time, two subsequent years $(2000$ and 2001) were dry, with over $23 \%$ of precipitation below the average of the observed period (Fig. 3d). It should be noted that similar observations for temperatures and precipitation were observed, regarding both plots, after 2006-2007 until 2009. Possible lag effect of a hot period on the second inventory period was not tested, due to lack of growth data after 2009. Even that some similar patterns were found in both areas, we can't result regarding climate growth (in terms of MRAPI) response comparing the three species due to that there are in different locations. The results regarding the reduction in this study are presented separately as numerical observations for each species and no deeper analysis or comparison between them will be attempted. On the other hand, species-specific sensitivity to warmer or drier climate could impact tree growth behavior directly but also indirectly through influences on forest composition and vitality (SAXE et al., 2001; Thuiller, 2004), a parameter which is not evaluated in this study.

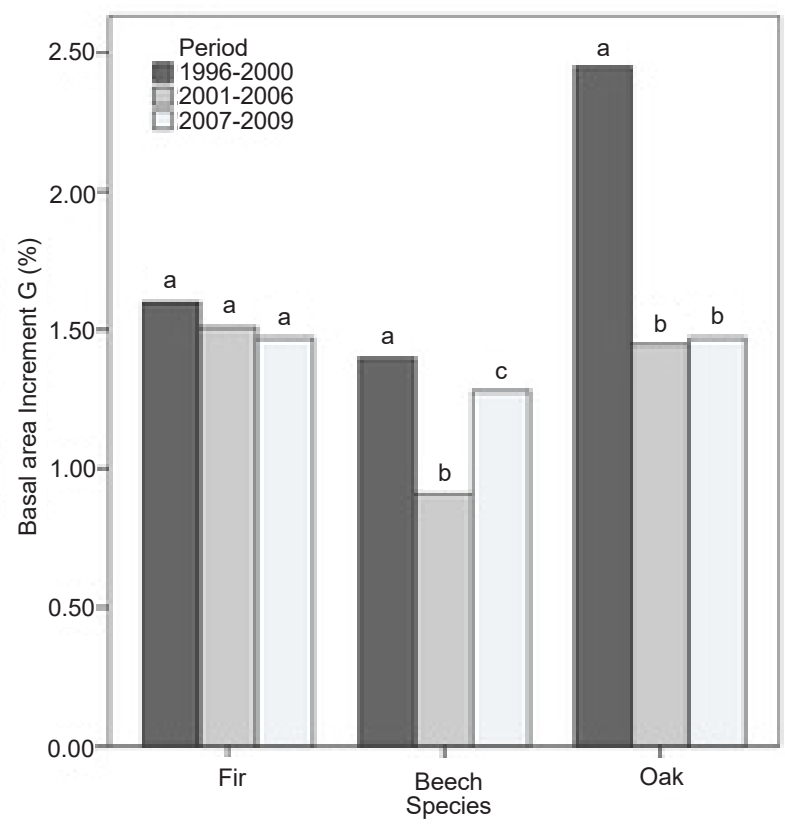

Fig. 4. ANOVA results showing Bonferroni's mutiple comparisons of relative basal area increment' means for the three study periods of the three species. Bars by the same letter are not statistically different.
The MRAPI is expressed as percentage (\%) of the basal area at the beginning of each period per tree species and plots (Fig. 4). For all tree species, reduced basal area growth observed during the period 2000-2006 compared to 1996-2000. After 2006, for oak and beech the MRAPI increased again. The MRAPI of basal area for fir was $1.60 \%$ during 1996-2000, $1.51 \%$ during 2000-2006 and $1.47 \%$ during 2006-2009. This reduction is considered rather low, suggesting that in general, basal area growth remained almost stable. This observation regarding fir, is confirmed as well by the analysis of variance, where there were no statistically significant differences between the three study periods (Fig. 4).

At the beech plot, analysis of variance showed that there were significant differences in MRAPI of basal area [European beech $(\mathrm{p}<0.05, \mathrm{n}=99)$ and Hungarian oak $(\mathrm{p}<0.05, \mathrm{n}=166)]$, between the three monitoring periods (Fig. 4), with considerable reduction (approximately $37 \%$ ) after 2000 (1.45 to $0.91 \%$ ), which was balanced after 2006 (1.28\% regarding the period 2006-2009). For oak, the results were similar. MRAPI declined from $2.45 \%$ in $1996-2000$, to $1.45 \%$ in $2000-2006$ and to 1.47 in 2006-2009, with no significant differences between the two last periods.

Similar results were found for tree volume (Fig. 5) with one differentiation. Among the three study periods, the analysis of the variance showed statistically significant differences in the MRAPI of volume for all the species, i.e. Bulgarian fir $(\mathrm{p}<0.05, \mathrm{n}=82)$, European beech $(\mathrm{p}<$ $0.05, \mathrm{n}=99)$ and Hungarian oak $(\mathrm{p}<0.05, \mathrm{n}=166)$ (Fig. 5). The particular MRAPI in fir plots reduced from 3.28 to

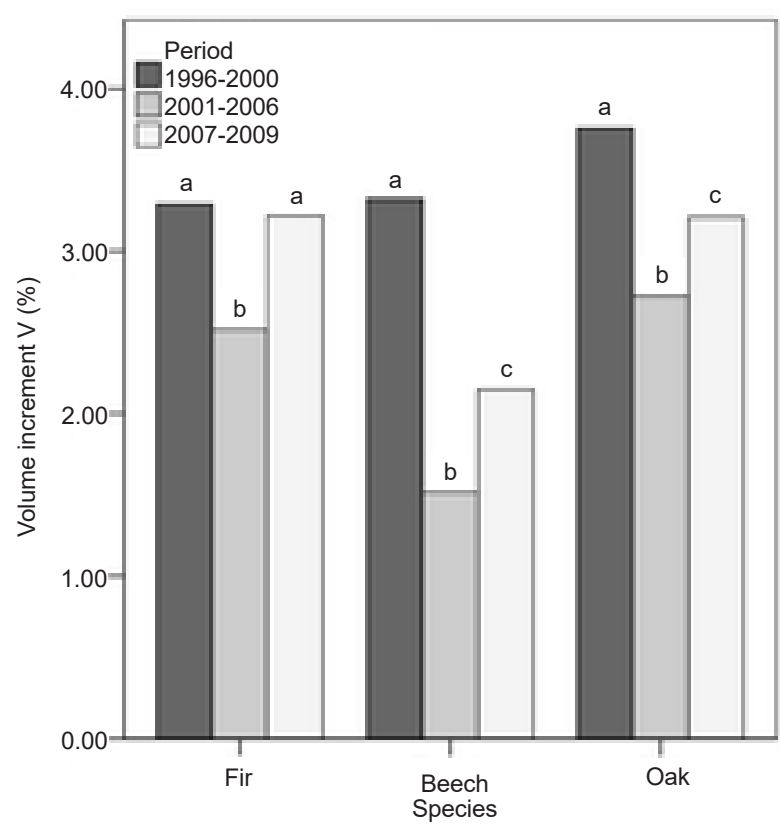

Fig. 5. ANOVA results showing Bonferroni's multiple comparisons of relative volume increment" means for the three study periods of the three species. Bars by the same letter are not statistically different. 
$2.51 \%$ between the first two periods (approximately 22\%) and increased by $3.21 \%$ during the last, almost reaching the levels of the first period. Similarly, in the first two periods in beech and oak declined from 3.32 to $1.51 \%$ and from $3.75 \%$ to $2.72 \%$, respectively.

The analysis of variance of the regression showed that the effect of temperature on MRAPI of the volume was not significant in any case even if that many combinations of temperatures (May to September, June to August, March to October, May to October etc.) were tested. On the contrary, after several tests we found significant positive correlations between MRAPI of volume and the total summer season precipitation (May-August) regarding oak and beech. This particular relationship was not found to be significant regarding fir. The correlation and the ANOVA regression results regarding the precipitation are presented in Table 2.

All the correlations were found to be positive and significant regarding beech and oak in contrast with the case of fir. The previously mentioned independent variable was found to be significant for tree volume increment with $\mathrm{r}$ $=0.757, \mathrm{R}_{\text {sqr }}=0.573$ for oak and $\mathrm{r}=0.550, \mathrm{R}_{\text {sqr }}=0.303$ for beech. Moreover, the $p$-value was 0.003 and 0.05 respectively, with acceptable standard errors of estimate and Durbin-Watson value (there is no autocorrelation).

\section{Discussion}

Changing water supply can severely alter above- and below-ground tree growth, as well as affects the vitality of trees (DobBERTIN, 2005). As summarized by DE VRIES et al. (2014), many tree-ring studies have successfully linked ring width reduction to reduced precipitation or increased temperature of various months during or before the current tree growing season. CAMARERo et al. (2013) showed that the previous year's climatic conditions had actually influence on current growth, during the past century. A positive relation between volume growth and summer precipitation underlies the strong dependence of mountain tree species (i.e. oak and beech) on summers' water availability (FYLLAS et al., 2017). In addition, an extreme event (e.g. the heat wave of 2003 in Europe) in the growing season would also affect early tree growth in the following year, on lowelevation deciduous broadleaved plots (BERTINI et al., 2011). In the present study, we observed growth increment decline (in terms of MARPI) in all three examined tree species, happened probably due to the heat and drought incidents during 1996-2000. In the Mediterranean zone, the rising temperatures and the projected rainfall decrease lead to increased drought risks; during hot periods, photosynthesis rates will decrease, resulting in lower biomass growth and yield (LIDNER et al., 2010). Based on the meteorological observations are in agreement with SPINONI et al. (2015) regarding the highest drought frequency and severity at the Aegean region (Greece included) that took place after 1990 .

The statistical analysis showed that temperature does not seem to be a strong predictor of MARPI of basal area and volume, regarding the examined tree species. Nevertheless, we confirm the importance of water availability for tree growth in Mediterranean forest ecosystems. Even that MARPI of basal area and volume correlation with precipitation were tested, only volume increment had significant relationship with summer precipitation. Therefore, concerning the examined period 1996-2009, reduced precipitation could result to considerable volume growth reduction. FyLLAS et al. (2017) indicated that precipitation during summer was a strong predictor of tree growth across seven Mediterranean tree species. It is important to highlight that volume calculation includes tree height measurement; therefore, it is highly possible that both height and radial growth are reduced. In other words, volume is not only a more sensitive parameter to reveal growth change differences from period to period, but also seems to detect more efficiently correlations with climatic conditions. In agreement to BREDA et al. (2006), drought results in the reduction of soil water availability, inducing restrictions to growth (both radial and height) and transpiration, as well as bud production. Our data and statistical analysis could not prove that the above statement, regarding significant relation between volume increment reduction and precipitation, is also valid for fir.

It has been observed that the declining trees are at a very high risk of dying (BIGLER et al., 2004). In agreement to our results, increased tree growth during the third inventory period (2006-2010) at a few sites could be clearly related to growth enhancement after stand density reducing events (ETzOLD et al. 2014). Drought tolerance in tree species has been described by HARTMANN (2011), suggesting that in large trees stomatal control of water loss hinders carbon assimilation and could lead to starvation during droughts. An important observation is that broadleaved forests (oak and beech) are characterized by

Table 2. Annual volume increment and total summer precipitation correlation and regression parameters.

\begin{tabular}{cccc}
\hline & Correlation Coefficient & Durbin-Watson & Regression \\
\hline Oak & 0.757 & 2.435 (Passed) & $\mathrm{R}_{\mathrm{sqr}}=0.573$ \\
Beech & 0.550 & 1.563 (Passed) & $\mathrm{R}_{\mathrm{sqr}}=0.303$ \\
Fir & 0.220 & 2.665 (Failed) & $\mathrm{R}_{\mathrm{sqr}}=0.050$ \\
\hline
\end{tabular}


predetermined early growth (PALLARDY, 2008); therefore, extreme events in the growing season will seriously affect the growth of the following season (BERTINI et al., 2011). Although, we cannot ignore that the fir plot was situated at a higher elevation with different site conditions (aspect, slope etc.) so the comparison between the species makes no sense. In central Europe, the extreme drought of 2003 led to the reduction of forest growth in low-elevation forests (up to 60\%), while high-elevation forests showed no growth change or increased growth (JoLLY et al., 2005). Furthermore, forest growth is influenced by internal factors (stand age, stand density, inter-tree competition, biotic damage) and external factors e.g. weather conditions, nutrient (more details are included in FERRETTI et al., 2014) and water supply, deposition, biotic/abiotic damage (LORENZ et al., 2004), and therefore, the above results do not entirely cover the subject of growth decline. For example, temperature-induced stress appears to become increasingly limiting as trees age, leading to higher climate sensitivity in older individuals (LINARES et al., 2011). An increasing sensitivity to climatic conditions may have a significant impact on predictions of future carbon uptake and forest dynamics in the Mediterranean Basin.

Given the economic importance of forestry and, more specifically, of the forest sector in relation to climate change, further questions arise regarding future timber harvests from sustainably managed forests.

Further, research on forest growth monitoring, using dendrochronology methods and long-term meteorological data, will expand our understanding of the effects of regional climatic conditions on tree distribution. Finally, the above mentioned current and future challenges regarding Mediterranean forests will provide useful scientific knowledge for local managers and policy makers, who can take the necessary steps to promote the protection and sustainable use of these forests.

\section{Conclusions}

As our world becomes increasingly warmer with more extreme weather events, decisions about forest management have increasingly greater impacts. Quantitative calculations about the forest growth and their growing conditions, which can be applied at various scales to compare several case studies, are crucial for forest ecosystems and human interaction. Likewise, similar calculations can be made to assess changes in forest ecosystems caused by different factors. It is a relatively straightforward matter to link these growth variations to climate change scenarios or regional meteorological events. This assumption was confirmed in our analysis by finding statistical significance between mean relative annual periodic increment of volume and summer precipitation for beech and oak plots which wasn't proved in the case of fir. Volume changes cannot be explained by temperatures in any case, although volume changes seem to detect better than basal area changes correlations of growth with climatic conditions.
The observations of increased growth decline, however, can also be interpreted more broadly in terms of mediumor long-term decreased production and/or value of forest products, especially when considering sustainably managed forests for wood production. Our observations were derived from samples of restricted size and specific sites, so our results should therefore be considered as evidences of growth changes, but not as general observations. Biometric data, from 2009 up to date will possibly confirm our results regarding the previous period. Long-term monitoring, further analysis of more tree species in additional plots, for the identification of potential decline or better resilience to climatic changes, are therefore important. Future forest management scenarios in Mediterranean forest ecosystems now include information such as the above, to support decision making that aims to manage these vulnerable ecosystems in a sustainable way. Over time, such research will become a high priority task.

\section{Acknowledgements}

The authors express their appreciation to the Ministry of Rural Development and Food, the Ministry of Environment, Energy and Climate Change and the European Commission, which financially sustain the Programme of "Effects of Atmospheric Pollutants on Forest Ecosystems" on the framework of which the current study was based. The authors want to express their sincere thankfulness to Dr Panagiotis Michopoulos (Scientific Coordinator of the Programme), the Forest Research Institute of Athens personnel for their help with the field data collection during all these years, the laboratory of Forest Hydrology as well as the librarian of the Institute Mrs D. Panayiotopoulou for her additional proof reading service. Finally, we would like to thank the Editor and the anonymous reviewers whose insightful comments helped to substantially improve the manuscript.

\section{References}

Allen, C.D., Macalady, A.K., Chenchouni, H., Bachelet, D., McDowell, N., Vennetier, M., Kitzberger T., Rigling A., Breshears, E.H., Hogg, T., Gonzales, P., Fensham, R., Zhang, Z., Castro, J., Demidova N., Lim J.H., Allard, G., Running S.W., Semerci, A., Cobb, N., 2010. A global overview of drought and heat-induced tree mortality reveals emerging climate change risks for forests. Forest Ecology and Management, 259: 660-684.

Apatsidis, L., SifaKIS, C., 1999. Electronic application (APSI) for the calculation of static and dynamic data of Beech, Fir, Oak, Spruce, Austrian, Aleppo, Brutian and Scots Pine and Cypress forest stands. User manual. Athens, Greece: National Agricultural Research Foundation, Institute of Mediterranean Ecosystems \& Forest Products Technology. $32 \mathrm{p}$.

Aussenac, G., 2002. Ecology and ecophysiology of circumMediterranean firs in the context of climate change. Annals of Forest Science, 59: 823-832. 
Bergmeier, E., Dimopoulos, P., 2001. Fagus sylvatica forest vegetation in Greece: syntaxonomy and gradient analysis. Journal of Vegetation Science, 12: 109-126.

Bergmeier, E., Dimopoulos, P., 2008. Identifying plant communities of thermophilous deciduous forest in Greece: species composition, distribution, ecology and syntaxonomy. Plant Biosystems, 142: 228-254.

Bertini, G., Amoriello, T., Fabbio, G., Piovosi, M., 2011. Forest growth and climate change: evidences from the ICP-Forests intensive monitoring in Italy. iForest, 4 : 262-267.

Bigler, C.J., Gricar, J., Bugmann, H., Cufar, K., 2004. Growth patterns as indicators of impending tree death in silver fir. Forest Ecology and Management, 199: 183-190.

Bréda, N., Huc, R., Granier, A., Dreyer, E., 2006. Temperate forest trees and stands under severe drought: a review of ecophysiological responses, adaptation processes and long-term consequences. Annals of Forest Science, 63: 625-644.

Camarero, J., Manzanedo, R.D., Sanchez-Salguero, R., NAVARRO-CERrillo, R.M., 2013. Growth response to climate and drought change along an aridity gradient in the southernmost Pinus nigra relict forests. Annals of Forest Science, 70: 769-780.

Caudullo, G., Tinner, W., 2016. Abies- Circum-Mediterranean firs in Europe: distribution, habitat, usage and threats. In San-Miguel-Ayanz, J., De Rigo, D., Caudullo, G., Houston Durrant, T., Mauri, A. (eds). European atlas of forest tree species. Luxembourg: Publications Office of the European Union, e015be7.

Ciais, P., Reichstein, M., Viovy, N., Granier, A., Ogee, J., Allard, V., Aubinet, M., Buchmann, N., Bernhofer, C., Carrara, A., Chevallier, F., De Noblet, N., Friend, A.D., Friedlingstein, P., Gruenwald, T., Heinesch, B., Keronen, P., Knohl, A., Krinner, G., Loustau, D., Manca, G., Matteucci, G., Miglietta, F., Ourcival, J.M., Papale, D., Pilegaard, K., Rambal, S., Seufert, G., Soussana, J.F., Sanz, M.J., Schulze, E.D., Vesala, T., VALENTINI, R., 2005. Europe-wide reduction in primary productivity caused by the heat and drought in 2003 . Nature, 437 (7058): 529-533.

De Vries, W., Dobbertin, M.H., Solberg, S., Van DobBEN, H.F., Schaub, M., 2014. Impacts of acid deposition, ozone exposure and weather conditions on forest ecosystems in Europe: an overview. Plant and Soil, 380: 1-45.

De VRIES, W., ReINDS, G.J., Vel, E., 2003. Intensive monitoring of forest ecosystems in Europe 2: atmospheric deposition and its impacts on soil solution chemistry. Forest Ecology and Management, 174: 97-115.

Dimopoulos, P., Bergmeier, E., Fischer, P., 2006. Natura 2000 habitat types of Greece evaluated in the light of distribution, threat and responsibility. Biology and Environment, Proceedings of the Royal Irish Academy, 106: 175-187.

DobBerTin, M., 2005. Tree growth as indicator of tree vitality and of tree reaction to environmental stress: a review. European Journal of Forest Research, 124: 319-333.

Dobbertin, M., Neumann, M., 2016. Part V., Tree growth. In UNECE ICP Forests, Programme Coordinating Centre (ed.). Manual on methods and criteria for harmonized sampling, assessment, monitoring and analysis of the effects of air pollution on forests. Eberswalde, Germany: Thünen Institute of Forest Ecosystems. 28 p.
Etzold, S., Waldner, P., Thimonier, A., Schmitt, M., DobBERTIN, M., 2014. Tree growth in Swiss forests between 1995 and 2010 in relation to climate and stand conditions: Recent disturbances matter. Forest Ecology and Management, 311: 41-55.

Fabbio, G., Bertini, G., Calderisi, M., Ferretti, M., 2006. Status and trend of tree growth and mortality rate at the CONECOFOR plots, 1997-2004. In Ferretti, M., Bussotti, F., Fabbio, G., Petriccione, B. (eds). Ecological condition of selected forest ecosystem in Italy. Status and changes 1995-2005. Fourth report of the Task Force on Integrated and Combined evaluation of the CONECOFOR programme. Annali Instituto Sperimentale per La Selvicoltura, 34: 11-20.

Ferretti, M., Marchetto, A., Arisci, S., Bussotti, F., Calderisi, M., Carnicelli, S., Cecchini, G., Fabbio, G., Bertini, G., Matteucci, G., De Cinti, B., Salvati, L., PoMPeI, E., 2014. On the tracks of nitrogen deposition effects on temperate forests at their southern European range - an observational study from Italy. Global Change Biology, 20: 3423-3438.

Fyllas, N.M., Christopoulou, A., Galanidis, A., MiChelaki, C.Z., Dimitrakopoulos, P.G., Fulé, P.Z., AriANOUTSOU, M., 2017. Tree growth-climate relationships in a forest-plot network on Mediterranean mountains. Science of the Total Environment, 598: 393-403.

Galiano, L., Martinez-Vilalta, J., Lloret, F., 2010. Drought-induced multifactor decline of Scots pine in the Pyrenees and potential vegetation change by the expansion of co-occurring oak species. Ecosystems, 13: 978991.

Hartmann, H., 2011. Will a 385 million year-struggle for light become a struggle for water and for carbon? How trees may cope with more frequent climate change-type drought events. Global Change Biology, 17: 642-655.

Houston Durrant, T., De Rigo, D., Caudullo, G., 2016. Fagus sylvatica and other beeches in Europe: distribution, habitat, usage and threats. In SAN-Miguel-Ayanz, J., De Rigo, D., Caudullo, G., Houston Durrant, T., MAURI, A. (eds). European atlas of forest tree species. Luxembourg: Publications Office of the European Union, p. $\mathrm{e} 012 \mathrm{~b} 90+$

IPCC, 2007. Climate Change 2007: impacts, adaptation and vulnerability. In Parry, M.L., Canziani, O.F., Palutikof, J.P., Van Der Linden, P.J., Hanson, C.E. (eds). Contribution of Working Group II to the Fourth Assessment Report of the Intergovernmental Panel on Climate Change. Cambridge: Cambridge University Press. 22 p.

IPCC, 2012. Managing the risks of extreme events and disasters to advance climate change adaptation. In FIELD, C.B., Barros, V., Stocker, T.F., Qin, D., Dokken, D.J., Ebi, K.L., Mastrandrea, M.D., Mach, K.J., Plattner, G.K., Allen, S.K., Tignor, M., Midgley, P.M. (eds). A Special Report of Working Groups I and II of the Intergovernmental Panel on Climate Change. Cambridge, UK, and New York, NY, USA: Cambridge University Press. 582 p.

Jolly, W.M., Dobbertin, M., Zimmermann, N.E., ReichSTEIN, M., 2005. Divergent vegetation growth responses to the 2003 heat wave in the Swiss Alps. Geophysical Research Letters, 32: L18409.

Linares, J.C., CAmarero, J.J., Carreira, J.A., 2009. Interacting effects of changes in climate and forest cover on mortality and growth of the southernmost European fir 
forests. Global Ecological Biogeography, 18: 485-497.

Linares, J.C., Tíscar, P.A., CAMARero, J.J., TAÏQui, L., Viñegla, B., Seco, J.I., Merino, J., Carreira, J.A., 2011. Tree growth decline on relict Western-Mediterranean mountain forests: causes and impacts. In Jenkins, J.A. (ed.). Forest decline: causes and impacts. Hauppauge, N.Y.: Nova Science Publishers, p. 522-533.

Lindner, M., Maroschek, M., Netherer, S., Kremer, A., Barbati, A., Garcia-Gonzalo, J., Seidl, R., Delzon, S., Corona, P., Kolström, M., LeXer, M.J., Marchetti, M., 2010. Climate change impacts, adaptive capacity, and vulnerability of European forest ecosystems. Forest Ecology and Management, 259: 698-709.

Lorenz, M., Becher, G., Mues, V., Fischer, R., Ulrich, E., Dobbertin, M., Stofer, S., 2004. Forest condition in Europe: 2004 technical report of ICP Forests. Work report of the Institute for World Forestry, No. 2004/2. Hamburg: Federal Research Centre for Forestry and Forest Products (BFH), Institute for World Forestry.

Mauri, A., Enescu, C.M., Houston Durrant, T., De Rigo, D., Caudullo G., 2016. Quercus frainetto in Europe: distribution, habitat, usage and threats. In SAN-MiguELAyanz, J., De Rigo, D., Caudullo, G., Houston DurRANT, T., MAURI, A. (eds). European atlas of forest tree species. Luxembourg: Publications Office of the European, p. e01de78+.

Merino, A., Real, C., Alvarez-Gonzalez, J.G., RodriGUEZ-GuITIAN, M.A., 2007. Forest structure and C stocks in natural Fagus sylvatica forest in southern Europe: the effects of past management. Forest Ecology and Management, 250: 206-214.

Michopoulos, P., Baloutsos, G., Economou, A., 2008. Nitrogen cycling in a mature mountainous beech forest. Silva Fennica, 42: 5-17.

Michopoulos, P., Bourletsikas, A., Kaoukis, K., Karetsos, G., Tsagari, C., Daskalakou, E., 2015. Assessment of the risk of nitrogen saturation in a mountainous fir stand. Fresenius Environmental Bulletin, 24: 1456-1462.

Pallardy, S.G., 2008. Physiology of woody plants. 3rd ed. Amsterdam: Elsevier Academic Press, 453 p.
Papadopoulos, A., 2016. Tree-ring patterns and climate response of Mediterranean fir populations in Central Greece. Dendrochronologia, 40: 17-25.

Peñuelas, J., Lloret, F., Montoya, R., 2001. Severe drought effects on Mediterranean woody flora in Spain. Forest Science, 47: 214-218.

Peñuelas, J., Sardans, J., Filella, I., Estiarte, M., Llusià, J., Ogaya, R., Carnicer, J., Bartrons, M., RivasUbach, A., Grau, O., Peguero, G., Margalef, O., PlaRabés, S., Stefanescu, C., Asensio, D., Preece, C., Liu, L., Verger, A., Barbeta, A., Achotegui-Castells, A., Gargallo-Garriga, A., Sperlich, D., Farré-ArmenGol, G., Fernández-Martínez, M., Liu, D., Zhang, C., Urbina, I., Camino-Serrano, M., Vives-Ingla, M., Stocker, B.D., Balzarolo, M., Guerrieri, R., Peaucelle, M., Marañón-Jiménez, S., Bórnez-Mejías, K., Mu, Z., Descals, A., Castellanos, A., Terradas, J., 2017. Impacts of global change on Mediterranean forests and their services. Forests, 8: 463.

Pressler, M., 1865. Das Gesetz der Stammbildung. Leipzig. Sánchez-Salguero, R., Camarero, J.J., Grau, J., De la Cruz, A.C., Gil, P.M., Minaya, M., Fernández-Cancio, Á., 2017. Analysing atmospheric processes and climatic drivers of tree defoliation to determine forest vulnerability to climate warming. Forests, 8: 13.

Saxe, H., Cannell M.G.R., Johnsen, Ø., Ryan, M.G., VouRLITIS, G., 2001. Tree and forest functioning in response to global warming. New Phytologist, 149: 369-400

Spinoni, J., Naumann, G., Vogt, J.V., Barbosa, P., 2015. The biggest drought events in Europe from 1950 to 2012. Journal of Hydrology: Regional Studies, 3: 509-524.

Thuiller, W., 2004. Patterns and uncertainties of species' range shifts under climate change. Global Change Biology, 10: 2020-2027.

Von WueHLISCH, G., 2008. EUFORGEN Technical guidelines for genetic conservation and use for European beech (Fagus sylvatica). Rome, Italy: Bioversity International. $6 \mathrm{p}$.

Received May 28, 2019 Accepted November 15, 2019 